\title{
ACUTE EFFECTS OF AQUEOUS LEAF EXTRACT OF ASPILIA AFRICANA C.D. ADAMS ON SOME HAEMATOLOGICAL PARAMETERS IN RATS
}

\section{${ }^{1 *}$ Kazeem Olasunkanmi Ajeigbe ${ }^{1}$ Seyi Samson Enitan, ${ }^{2}$ Dayo Rotimi Omotoso and ${ }^{3}$ Olayemi Olutobi Oladokun.}

\author{
Department of ${ }^{1}$ Physiology and ${ }^{2}$ Anatomy, School of Basic Medical Sciences \\ Igbinedion University, Okada, Edo State, Nigeria. ${ }^{3}$ Department of Physiology, Osun State University, \\ Osogbo. \\ *Email; kazeemajeigbe@gmail.com
}

\begin{abstract}
Several medicinal plants have been documented for their haematological effects either at low or high concentration but very little is known about Aspilia africana. The aim of the study was to investigate the acute effects of aqueous leaf extract of Aspilia africana at different concentrations on some haematological parameters in rats. Following 14 days of oral administration of aqueous extract of A. africana, Haematocrit $(H C T)$, Haemoglobin concentration $(H B)$, Mean Cell Haemoglobin Concentration (MCHC), Red Blood Cell Count (RBC Count), Total White Blood Cell Count (Total WBC Count), Absolute Neutrophils count (NEUT\#), Absolute Lymphocytes count (LYM\#), Absolute Eosinophils Count (EOSIN\#) and Absolute Monocytes (MONO\#) were evaluated in twenty (20) male Wistar albino rats. The rats weighed $174 \pm 20 \mathrm{~g}$, and were randomly assigned into 4 groups viz: Group 1, Control; Group 2, 250mg/Kg/d aqueous extract; Group 3, 500mg/Kg/d aqueous extract; and Group 4, 750mg/Kg/d aqueous extract. HCT, HB, MCHC, RBC Count, Total WBC Count, NEUT\#, LYM\#, EOSIN\# and MONO\# were significantly increased $(P<0.001)$ in $500 \mathrm{mg} / \mathrm{Kg} / \mathrm{d}$ of A. africana extract $\left(61.13 \pm 1.65 \%, 13.5 \pm 1.29 \mathrm{~g} / \mathrm{dl}, 23.33 \pm 0.0 .02 \mathrm{~g} / \mathrm{dl}, 3.68 \pm 0.02 \times 10^{12} \mathrm{Cells} / \mathrm{l}, 2.33 \pm 0.02 \times 10^{9} \mathrm{Cells} / 1,1.32 \pm 0.04 \times 10^{9} \mathrm{Cells} / \mathrm{l}\right.$, $1.43 \pm 0.05 \times 10^{9} \mathrm{Cells} / \mathrm{l}, 0.47 \pm 0.02 \times 10^{9} \mathrm{Cells} / \mathrm{l}$ and $0.47 \pm 0.04 \times 10^{9} \mathrm{Cells} / \mathrm{l}$, respectively) when compared to the Control $\left(51.13 \pm 0.85 \%, 9.56 \pm 0.43 \mathrm{~g} / \mathrm{dl}, 19.22 \pm 0.19 \mathrm{~g} / \mathrm{dl}, 2.69 \pm 0.01 \times 10^{12} \mathrm{Cells} / 1,1.79 \pm 0.01 \times 10^{9} \mathrm{Cells} / 1,0.80 \pm 0.00 \times 10^{9} \mathrm{Cells} / \mathrm{l}\right.$, $0.83 \pm 0.00 \times 10^{9} \mathrm{Cells} / \mathrm{l}, 0.18 \pm 0.00 \times 10^{9} \mathrm{Cells} / 1$ and $0.24 \pm 0.00 \times 10^{9} \mathrm{Cells} / 1$, respectively) which received no extract at all. The $500 \mathrm{mg} / \mathrm{Kg}$ of $A$. africana extract proved to be the most effective, while the $750 \mathrm{mg} / \mathrm{Kg}$ proved to be the least effective in comparison with the control. The results of this study further strengthened the earlier works on the medicinal benefits of Aspilia africana and its virtue as a good pharmacological source of haematopoiesis.
\end{abstract}

Key words: Aspilia Africana, haematology, rats.

\section{Introduction}

Human's dependency and sustainability have continued to revolve around plants through their uses as foods, fibres, shelters, and even medicines. The use of plants as medicine is an ancient and reliable practice (Balick and Paul, 1996). Plant materials and products continue to play an important role in the maintenance of human health since antiquity. They are the major source of drug development in the pharmaceutical industry (Burton et al., 1983). Several plants are now being used in part or as a whole to treat many diseases. Active components of these plants are now being investigated, extracted and developed into drugs with little or no negative effects or contra-indications (Oluyemi et al., 2007).

In Nigeria, many indigenous plants are used in herbal medicine to cure diseases and heal injuries. Aspilia africana is one of such medicinal plants, which are fast gaining recognition. It is a semi woody herb occurring throughout the regions of the savannah and tropical Africa on wastelands (Hutchinson, 1962; Burkill, 1985). It is known by various names among the Nigerian populace (Orangila in Igbo, Tozalin in Hausa and Yunyun in Yoruba). The plant has been reported in literature to possess antimicrobial (Macfoy and Cline, 1990), haemostatic (Achonye, 1976), anti-inflammatory (Okoli et al., 2006) and anti-fertility (Eweka, 2007) activity. The wound healing and anti-ulcer activity of its n-hexane and methanolic extracts have also been reported (Nguelefack et al., 2005; Okoli et al., 2007). In South-eastern Nigeria, leaves of this plant is claimed to be effective in the treatment of stomach ache and bleeding gastric ulcers, especially when taken as an aqueous decoction.

Phytochemical analysis of the plant reveals that it has a high crude oil and protein content (Burkill, 1985). It is also rich in saponin, tannins, glycoside and alkaloids (Adeniyi and Odufowora, 2000; Iwu, 1993). Kuiate et al. (1999) reported the presence of four essential oils obtained by hydrodistillation of the leaves of Aspilia africana. These oil samples included sesquiterpenes, monoterpenes, germacrened and alpha-pienene.

Medicinal plants have been documented for their haematological effects either at low or high concentration (Garima and Goyal, 2007; Nwinuka et al., 2008; Ikpu and Nku, 2008; Odesanmi et al., 2010; Oyedemi et al., 2011; Tatfeng and Enitan, 2012), but very little is known about Aspilia africana in this regard. There seems to be limited scientific evidence on the use of Aspilia africana in modulation of haematopoetic function and the mechanism by which this function may occur. With increasing statistics on the number of deaths resulting from haematopoietic disorders and blood related diseases, it has become very crucial to seek both economic and accessible alternative medicine that could serve as natural haematopoieticstimulating agent. 


\section{Ajeigbe et al., Afr J Tradit Complement Altern Med. (2013) 10(5):236-243 http://dx.doi.org/10.4314/ajtcam.v10i5.4}

The aim of this work was to investigate the effects of aqueous leaf extract of Aspilia africana at varying doses on some haematological parameters in adult Wistar albino strain rats. This investigation will establish if the anticipated effects are stimulatory or inhibitory, and also dose-dependent.

\section{Materials and Method \\ Animals}

Twenty (20) male albino rats weighing $174 \pm 20 \mathrm{~g}(\mathrm{mean} \pm \mathrm{SD})$ were purchased from the Animal Production and Health Department, University of Benin, Benin, and housed in the Experimental Animal House, College of Health Sciences, Igbinedion University Okada, Nigeria in well ventilated wire-bottom steel cages under hygienic conditions, at $25 \pm 2^{\circ} \mathrm{C}$, and a relative humidity of $45-50 \%$. The rats were fed on a commercially available diet produced by Bendel Feed and Flour Mills Limited $(10 \mathrm{~g} / 100 \mathrm{~g}$ body weight) twice daily and tap water ad libitum. Prior to commencement of administration, the rats were allowed to stabilise in the Animal House with standard 12-hour light-dark cycle, for a period of 14 days, and were treated for 14 days with different doses of the plant extracts. All studies on animal experimentation were conducted in accordance with the Current Animal Care Regulations and Standards approved by the Institute for Laboratory Animal Research (ILAR, 1996).

\section{Preparation of Aqueous Aspilia africana Extract}

A bulk of fresh Aspilia africana leaves (single batch) sufficient for the study was collected from the field. The leaves were air-dried and grounded to fine powder. About $60 \mathrm{~g}$ of the plant powder were weighed using Mettler weighing balance and homogenised in a clean electric blender containing $80 \mathrm{ml}$ sterile distilled water according to the method described by Sofowora (1982). These gave $750 \%$ concentration (using $7.5 \mathrm{~g} / 10 \mathrm{ml}$ ). The homogenates (amber green solution) were shaken for $1 \mathrm{hr}$ in a rotary flask and after 72 hours, filtered into separate sterile containers using a funnel containing sterile cotton wood and later with Whatman No. 1 filter paper. The liquid filtrates were transferred into sterile MacCartney bottles and stored in the refrigerator after daily administration to the experimental animals.

\section{Preparation of Different Concentration of the Extracts}

After preparation of the crude extracts as described, additional concentrations $(500 \mathrm{mg} / \mathrm{Kg}$ and $250 \mathrm{mg} / \mathrm{Kg}$ ) were made from the stock $(750 \mathrm{mg} / \mathrm{Kg})$ with sterile distilled water aseptically. Extracts were stored in the refrigerator at $4^{\circ} \mathrm{C}$ to maintain their potency.

\section{Experimental design}

The animals were randomly assigned into four (4) groups of five rats each ( $\mathrm{n}=5 /$ group) and treated as follows:

Group 1: Control group, received no extract at all.

Group 2: $250 \mathrm{mg} / \mathrm{Kg} / \mathrm{d}$ aqueous extract of Aspilia africana

Group 3: $500 \mathrm{mg} / \mathrm{Kg} / \mathrm{d}$ aqueous extract of Aspilia africana

Group 4: $750 \mathrm{mg} / \mathrm{Kg} / \mathrm{d}$ aqueous extract of Aspilia africana

Oral gavages using a metal oropharyngeal canula and calibrated hypodermic syringe as described by ACF (2000) were employed in the administration of the aqueous extract of Aspilia africana once daily for 14 days at a volume of $2 \mathrm{ml} / 100 \mathrm{~g}$ body weight. Prior to sacrifice, the animals were starved of food overnight and sacrificed by cervical dislocation as described by Ochei and Kolhatkar (2006) a day after the administration of extracts was stopped.

\section{Blood Collection}

Blood samples were taken from each rat by terminal bleeding from the heart and transferred into a clean EDTAcontainer (thoroughly mixed) ready for haematological investigations.

\section{Evaluation of Haematological Parameters}

\section{Haematocrit Determination}

Haematocrit (Packed cell volume) was determined by microhaematocrit method as described by Cheesbrough (2000a). Briefly, the anti-coagulated blood was well mixed and the blood was collected into a plain capillary tube by capillary attraction to about three quarters $(3 / 4)$ of the tube, leaving at least $15 \mathrm{~mm}$ of the capillary unfilled. The outside of the tube was cleaned with cotton wool to remove blood. The capillary tubes were then sealed with plasticine. The capillary tubes were centrifuged for 5 minutes at a predetermined speed $(12000 \mathrm{rpm})$ in a microhaematocrit centrifuge, after which, the haematocrit was immediately read using a microhaematocrit reader and the result expressed as percentages. Each test was performed in duplicate and the mean taken.

\section{Haemoglobin Concentration Estimation}

Haemoglobin concentration was estimated using the Sahli acid haematin method, as described by Cheesbrough (2000b). $0.02 \mathrm{ml}$ of blood was mixed in a dilution tube containing $0.1 \mathrm{~mol} / 1$ hydrochloric acid (HCL) which converts the haemoglobin to acid haematin. After 10 minutes of reaction time, $0.1 \mathrm{~mol} / 1 \mathrm{HCl}$ was added drop by drop, with mixing, until 
the colour of the solution (haemolysed blood) matches the colour of the permanent coloured glass comparison standard positioned alongside the dilution tube in bright diffuse day light with a sheet of white paper as background. The concentration of haemoglobin was read from the graduation at the bottom of the meniscus on the dilution tube. The relative haemoglobin value obtained was converted to absolute haemoglobin value using the standard table of comparison provided. The test was performed in triplicate for each sample to reduce the level of imprecision and inaccuracy reported to be associated with this method of haemoglobin estimation.

\section{Determination of Mean Cell Haemoglobin Concentration}

The Mean Cell Haemoglobin Concentration (MCHC) was calculated by dividing the haemoglobin value ( $\mathrm{g} / \mathrm{dl})$ by the haematocrit value (expressed as decimal fraction) as described by Cheesbrough (2000a).

$$
\mathrm{MCHC}=\mathrm{Hb} / \mathrm{HCT}(\mathrm{g} / \mathrm{dl})
$$

\section{Red Blood Cell Count}

Red Blood Cell Count was carried out according to the method as described by Baker et al., (2001a). Briefly, $0.02 \mathrm{ml}$ of blood sample was diluted in $4.0 \mathrm{ml}$ of red cell diluting fluid (formol citrate) to give a final dilution of 1 in 200 . The diluted sample was then mixed and loaded into a haemocytometer. When the cells settled out of suspension, the number lying on 5 of the 25 small squares in the central area were counted in accordance to the Thoma counting rule. The final result was expressed as the number of cells per litre of blood using the formula below:

$\mathrm{RBC}$ Count $=\underline{\mathrm{N} X \mathrm{DF} X 10^{6}}$

A X D

Where $N=$ the number of cells counted, $D F=$ the dilution factor $(1$ in 200) of blood, $A=$ area of chamber counted $(5 \times 0.04$ $\left.\mathrm{mm}^{2}=0.2 \mathrm{~mm}^{2}\right), D=$ depth of chamber $(0.1 \mathrm{~mm})$.

\section{Total White Blood Cell Count}

Total White Blood Cell Count was carried out according to the method as described by Cheesbrough (2000c). Briefly, $0.02 \mathrm{ml}$ of blood sample was diluted in $0.38 \mathrm{ml}$ of white cell diluting fluid (Turk's solution) to give a final dilution of 1 in 20. The diluted sample was then mixed and loaded into the Improved Neubauer Counting Chamber. The chamber was left undisturbed for 2 minutes to allow time for the white cells to settle. When the cells have settled out of suspension, the numbers of cells present in the 4 corner $1 \mathrm{~mm}^{2}$ areas (total area of $4 \mathrm{~mm}^{2}$ ) were counted in accordance to the Thoma counting rule. The final result was expressed as the number of cells per litre (1) of blood using the calculation below:

WBC Count $=\underline{\mathrm{NX} \text { DFX } 10^{6}}$

$\mathrm{AX} \mathrm{D}$

Where $N=$ the number of cells counted, $D F=$ the dilution factor $(1$ in 20$)$ of blood, $A=$ area of chamber counted $\left(4 \mathrm{~mm}^{2}\right), D$ $=$ depth of chamber $(0.1 \mathrm{~mm})$.

\section{Differential White Blood Cell Count}

Differential White Blood Cell Count was similarly carried out according to the method as described by Cheesbrough (2000d). A drop of well-mixed blood was placed on a clean grease free slide about $1 \mathrm{~cm}$ from the edge. A spreader was then placed in front of the drop of blood and drawn back so that it touches the blood at an angle of $45^{\circ}$ allowing the blood to spread along the edge of the spreader. This was then pushed forward and rapidly. The film was then allowed to air-dry. The dried blood film was placed on a staining rack and the film was fixed with 1-2 drops of moisture-free absolute methanol (methyl alcohol) and stained with Leishman stain for 2 minutes. The stained film was diluted with twice as much buffered distilled water ( $\mathrm{pH}$ 6.8) and allowed to stand for 8 (eight) minutes. This was then washed with buffered distilled water (pH 6.8) until it was salmon pink in colour. The back of the slide was wiped using dry cotton wool and was allowed to air-dry. A drop of immersion oil was placed on the lower third of the dry blood film and covered with a clean cover glass. The film was examined microscopically to check the staining and distribution of cells using the 10x objective with the condenser iris closed sufficiently to see the cells clearly. The field was moved to a part of the film where the red cells were just beginning to overlap, and then the 40x objective was brought into place with the iris diaphragm more open. The blood film was examined systematically using the battlement method as described by Baker et al., (2001b) by being transverse three fields along and two fields down. The different white cells seen in each field were identified, counted and recorded on a chart until 100 white cells were counted. The absolute number of each white cell type was calculated by multiplying the number of each cell counted (expressed as a decimal fraction) by the total WBC count. Absolute \# Count = Number of \# cell counted X Total WBC Count.

\section{Statistical Analysis}

Data were presented as mean \pm SD and analysed using one way analysis of variance (ANOVA) and Tukey-Kramer Multiple Comparisons Test using SPSS-18.0 (Statistical Packages for Social Scientists - version 18.0) statistical program. P values $<0.05$ were considered significant. 

http://dx.doi.org/10.4314/ajtcam.v10i5.4

\section{Results}

The effects of extract of Aspilia africana leaves on various haematological parameters investigated in rats are presented in Table 4.1 and Figure 4.1.

\section{Effect of aqueous leaf extract of Aspilia africana on Haematocrit and Haemoglobin concentration}

The Mean \pm SD Haematocrit and Haemoglobin concentration of the $250 \mathrm{mg} / \mathrm{Kg}(54.5 \pm 1.29 \% ; 11.45 \pm 0.13 \mathrm{~g} / \mathrm{dl}$, respectively) and $500 \mathrm{mg} / \mathrm{Kg}(61.13 \pm 1.65 \% ; 13.5 \pm 1.29 \mathrm{~g} / \mathrm{dl}$, respectively) extracts of Aspilia africana leaves were found to be significantly higher (at $\mathrm{P}<0.05$ and $\mathrm{P}<0.001$, respectively) than the control $(51.13 \pm 0.85 \% ; 9.56 \pm 0.43 \mathrm{~g} / \mathrm{dl}$, respectively) in a dose-dependent manner, except the $750 \mathrm{mg} / \mathrm{Kg}(48.43 \pm 1.09 \% ; 10.33 \pm 0.28 \mathrm{~g} / \mathrm{dl}$, respectively) extract, post-administration (Table 4.1).

Also, the effect of extract of Aspilia africana on Mean Cell Haemoglobin concentration at the various doses $(250 \mathrm{mg} / \mathrm{Kg}: 21.38 \pm 0.22 \mathrm{~g} / \mathrm{dl} ; 500 \mathrm{mg} / \mathrm{Kg}: 23.33 \pm 0.02 \mathrm{~g} / \mathrm{dl}$ and $750 \mathrm{mg} / \mathrm{Kg}: 21.70 \pm 1.25 \mathrm{~g} / \mathrm{dl})$ tested were found to be significantly higher $(\mathrm{P}<0.01, \mathrm{P}<0.001$ and $\mathrm{P}<0.001$, respectively) than the control $(19.22 \pm 0.19 \mathrm{~g} / \mathrm{dl})$ post-administration, with the $500 \mathrm{mg} / \mathrm{Kg}$ showing the highest activity (Table 4.1 ).

\section{Effect of aqueous leaf extract of Aspilia africana on Red Blood Cell count and White Blood Cell count}

The Red Blood Cell count of the animals treated with the extracts at $250 \mathrm{mg} / \mathrm{Kg}\left(3.23 \pm 0.03 \times 10^{12} \mathrm{Cells} / \mathrm{l}\right)$ and $500 \mathrm{mg} / \mathrm{Kg}\left(3.68 \pm 0.02 \times 10^{12} \mathrm{Cells} / \mathrm{l}\right)$ doses were significantly higher than the control $\left(2.69 \pm 0.01 \times 10^{12} \mathrm{Cells} / \mathrm{l}\right)$ at $\mathrm{P}<0.001$, except the $750 \mathrm{mg} / \mathrm{Kg}\left(2.53 \pm 0.02 \times 10^{12} \mathrm{Cells} / \mathrm{l}\right)$. Similarly, Total White Blood Cell Count of the test groups at $500 \mathrm{mg} / \mathrm{Kg}$ $\left(2.33 \pm 0.02 \times 10^{9} \mathrm{Cells} / \mathrm{l}\right)$ dose of the extract in particular was significantly higher $(\mathrm{P}<0.001)$ than the control $(1.79 \pm 0.01 \mathrm{X}$ $\left.10^{9} \mathrm{Cells} / \mathrm{l}\right)$.

\section{Effect of aqueous leaf extract of Aspilia africana on Differential White Blood Cells count}

The effects of Aspilia africana on the Absolute Neutrophils count and Absolute Lymphocytes count postadministration were both significantly higher in $250 \mathrm{mg} / \mathrm{Kg}\left(0.93 \pm 0.02 \times 10^{9} \mathrm{Cells} / \mathrm{l} ; 0.97 \pm 0.02 \times 10^{9} \mathrm{Cells} / 1\right.$, respectively $)$ and $500 \mathrm{mg} / \mathrm{Kg}\left(1.32 \pm 0.04 \times 10^{9} \mathrm{Cells} / 1 ; 1.43 \pm 0.05 \times 10^{9} \mathrm{Cells} / \mathrm{l}\right.$, respectively) groups at $\mathrm{P}<0.05$ and $\mathrm{P}<0.001$ respectively, except $750 \mathrm{mg} / \mathrm{Kg}\left(0.72 \pm 0.09 \times 10^{9} \mathrm{Cells} / \mathrm{l} ; 0.76 \pm 0.10 \times 10^{9} \mathrm{Cells} / \mathrm{l}\right)$ that was significantly reduced when compared to the control $\left(0.80 \pm 0.00 \times 10^{9} \mathrm{Cells} / \mathrm{l} ; 0.83 \pm 0.00 \times 10^{9} \mathrm{Cells} / \mathrm{l}\right)$. Regarding the effects of Aspilia africana on the Absolute Eosinophils Count and Absolute Monocytes Count, only the $500 \mathrm{mg} / \mathrm{Kg}$ group $\left(0.47 \pm 0.02 \times 10^{9} \mathrm{Cells} / 1 ; 0.47 \pm 0.04 \mathrm{X}\right.$ $10^{9} \mathrm{Cells} / \mathrm{l}$, respectively) was significantly higher than the control $\left(0.18 \pm 0.00 \times 10^{9} \mathrm{Cells} / \mathrm{l} ; 0.24 \pm 0.00 \times 10^{9} \mathrm{Cells} / \mathrm{l}\right.$, respectively) at $\mathrm{P}<0.01$ (Fig. 4.1).

Table 4.1: Haematological Profile of Rats Administered with Different Concentrations of Aqueous Extract of Aspilia africana

\begin{tabular}{|c|c|c|c|c|c|c|}
\hline GROUP & TREATMENT & HCT (\%) & $\begin{array}{l}\mathrm{HB} \\
(\mathrm{g} / \mathrm{dl})\end{array}$ & $\begin{array}{c}\mathrm{MCHC} \\
(\mathrm{g} / \mathrm{dl})\end{array}$ & $\begin{array}{c}\mathrm{RBC} \\
\text { Count } \\
\left(. . \times 10^{12} \mathrm{Cel}\right. \\
1 / 1)\end{array}$ & $\begin{array}{c}\text { WBC } \\
\text { Count } \\
\left(. . \times 10^{9} \text { Cell }\right. \\
/ 1)\end{array}$ \\
\hline 1 & $\begin{array}{l}\text { Distilled Water } \\
(20 \mathrm{ml} / \mathrm{Kg} \mathrm{b} . \mathrm{w})\end{array}$ & $\begin{array}{c}51.13 \pm 0.8 \\
5\end{array}$ & $9.56 \pm 0.43$ & $\begin{array}{c}19.22 \pm 0.1 \\
9\end{array}$ & $2.69 \pm 0.01$ & $1.79 \pm 0.01$ \\
\hline 2 & $\begin{array}{c}\text { Aqueous Leaf } \\
\text { Extract of Aspilia } \\
\text { africana } \\
(250 \mathrm{mg} / \mathrm{Kg} \mathrm{b.w})\end{array}$ & $54.5 \pm 1.29$ & $\begin{array}{c}11.45 \pm 0.1 \\
3^{*}\end{array}$ & $\begin{array}{c}21.38 \pm 0.2 \\
2^{*}\end{array}$ & $3.23 \pm 0.03^{*}$ & $1.93 \pm 0.03$ \\
\hline 3 & $\begin{array}{c}\text { Aqueous Leaf } \\
\text { Extract of Aspilia } \\
\text { africana } \\
(500 \mathrm{mg} / \mathrm{Kg} \mathrm{b.w})\end{array}$ & $\begin{array}{c}61.13 \pm 1.6 \\
5^{*}\end{array}$ & $13.5 \pm 1.29^{*}$ & $\begin{array}{c}23.33 \pm 0.0 \\
2^{*}\end{array}$ & $3.68 \pm 0.02^{*}$ & $2.33 \pm 0.02^{*}$ \\
\hline 4 & $\begin{array}{c}\text { Aqueous Leaf } \\
\text { Extract of Aspilia } \\
\text { africana } \\
\text { (750 mg/Kg b.w })\end{array}$ & $\begin{array}{c}48.43 \pm 1.0 \\
9\end{array}$ & $\begin{array}{c}10.33 \pm 0.2 \\
8\end{array}$ & $\begin{array}{c}21.70 \pm 1.2 \\
5^{*}\end{array}$ & $2.53 \pm 0.02$ & $1.73 \pm 0.17$ \\
\hline
\end{tabular}




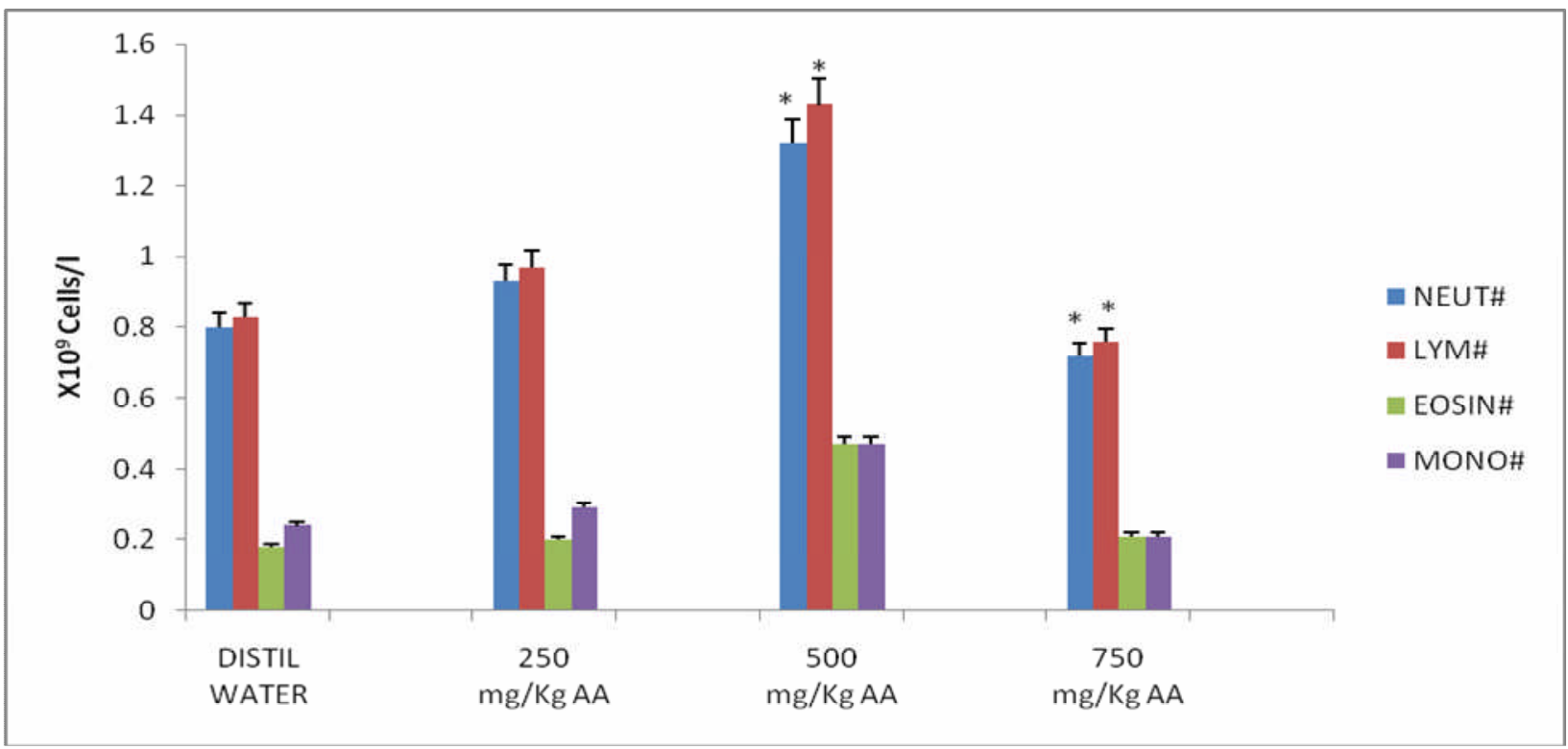

Fig. 4.1: Effect of aqueous extract of Aspilia africana on differential white blood cell counts in albino Wistar rats. Each vertical bar represents Mean \pm SD of five rats per group. $\left({ }^{*} \mathrm{p}<0.05 \mathrm{cf}\right.$ control)

NEUT\# = Absolute Neutrophil Count $\left(\ldots x 10^{9}\right.$ Cell/l), LYM\# = Absolute Lymphocyte Count $\left(. . . x 10^{9}\right.$ Cell/l), EOSIN\# = Absolute Eosinophils Count $\left(\ldots x 10^{9}\right.$ Cell/l), MONO\# = Absolute Monocytes Count $\left(\ldots x 10^{9}\right.$ Cell/l). AA =Aspilia africana.

\section{Discussion}

Investigation of haematological parameters represents a useful process in the diagnosis of many diseases as well as investigation of the extent of damage to the blood (Onyeyili et al., 1991). This is relevant since blood constituents change in relation to the physiological conditions of the animals. Haematological studies are important because blood is the major transport system of the body, and evaluation of the haematological profile usually furnishes vital information on the body's response to injury of all forms, including toxic injury (Schalm et al., 1975, and Ihedioha et al., 2004). Haematological constituents reflect the physiological responsiveness of the animal to its internal and external environments which include feed and feeding (Esonu et al., 2001) as well as drugs (Iheukwumere et al., 2007).

The purpose of this research work was to determine the effects of oral administration of Aspilia africana at different concentrations on some haematological parameters in rats. The varied level of significance noticed in the haematological parameters evaluated in this study (post-administration) between the control and the test groups, and even within the test groups shows that there is an obvious connection between the extracts (at the various concentrations tested) and the degree of haematological effects observed. The outcome of this present study shows that extract of Aspilia africana, particularly at $500 \mathrm{mg} / \mathrm{Kg}$ concentration, has significant impacts on the various haematological parameters investigated as evident in the active proliferations of blood components to varied extent as measured in the test groups, compared to the control. The appreciable increase in the values of the haematological parameters investigated may be associated with the inherent-haematopoietic-stimulating properties possessed by the extract of Aspilia africana.

Although there seems to be limited information regarding the effects of these extracts on blood parameters particularly in rats, the result of this present work agrees with that of Etim and Oguike (2011) in which Dutch breed rabbit does aged 6 to 7 months were used to investigate the effect of fresh and wilted Aspilia africana leaves as forage (500g per doe per day) on their haematological profiles. The results of the study showed that the lactating does fed with fresh and wilted Aspilia africana leaves had significantly higher HCT, Hb concentration, and RBC Count than the control rabbits fed 
with mixed forages without Aspilia africana leaves. On the other hand, the total WBC Count, Absolute Neutrophil Count Lymphocyte Count, Eosinophils Count and Monocytes Count of the fresh and wilted Aspilia africana leaves fed rabbit doe as reported by Etim and Oguike (2011) show no significant differences when compared to the control fed with mixed forages without Aspilia africana leaves.

$\mathrm{HCT}, \mathrm{Hb}, \mathrm{RBC}$ and MCHC are particularly important for the diagnosis of anaemia in humans and most animals. The values obtained in this current study for HCT, Hb, RBC and MCHC seem to be within the normal range as reported by Mitruka and Rawnsley (1977); Annon (1980); Ihedioha et al., (2004), suggesting the animals were not anaemic. Besides, the test groups had higher values for these parameters than the control, which indicates that a more efficient erythropoesis occur following administration of the extracts. Unlike the findings of Etim and Oguike (2011), there was a significant difference in the values for total WBC count between the control and the test groups, particularly the $500 \mathrm{mg} / \mathrm{Kg}$ extract of A. africana. Obviously, the extract at this concentration induced leucocytosis in the test rats, further confirming the anti-infective potential of this extract in this regard. This may indicate a more effective antibody production and the reason for better disease resistance and longevity as reported by Nwosu (1979) which is evident by low mortality. In most clinical situations, when a total WBC count is requested, it is usual to perform also a differential WBC count in order to provide information on the proportion of the different white cells present in circulating blood (Cheesbrough, 2000; Tatfeng and Enitan, 2012). In this study, the absolute count of lymphocytes, neutrophils, monocytes and eosinophils in the test groups were observed to be significantly increased when compared to the control. Obviously, these extracts must have induced lymphocytosis, neutrophilia, monocytosis and eosinophilia respectively, in the experimental animals to a varied extent, yet, confirming the anti-infective potential of the extract. Of all the white blood cell population counted, the lymphocytes were the mostly proliferated cells, followed by the neutrophils, monocytes and lastly the eosinophils.

One of the major functions of lymphocyte is their response to antigen (foreign bodies) by forming antibodies that circulate in the blood or in the development of cellular immunity. From the result of the differential white cell count carried out in this study, the higher values obtained for lymphocyte in the test group suggests a more effective antibody production as reported by Frandson (2003). This result may explain why the rats administered with A. africana performed better than the control in this regard, since A. africana seems to possess a wide range of biological activity including antiviral, fungicide and antibacterial activities (Masato and Wu, 1994). Also, A. africana has exhibited differential anti-infective activities on both gram-positive and gram-negative bacteria species (Mcfoy et al., 1990; Adeniyi et al., and Odufowora 2000).

Just as reported by Etim and Oguike (2011), the haematology analysis of the experimental animals administered with extract of Aspilia africana in this present study showed that A. africana could stimulate different blood cell lines to proliferate, thus exhibiting a hallmark effect in the haematopoietic micro-environment. Therefore, it may be found useful (particularly at $500 \mathrm{mg} / \mathrm{Kg}$ dose) in the improvement and maintenance of the haematological status of both anaemic and nonanaemic animals, respectively.

Since all the haematological parameters investigated in this study fall within the normal range of values reported by Mitruka and Rawnsley (1977), it may be assumed that the test plant (Aspilia africana) did not have adverse effects on the animals during the experimental period which lasted for only 14 days. However, the lower haematological effect observed with the $750 \mathrm{mg} / \mathrm{Kg}$ of the extract in comparison with the control and other test groups $(250 \mathrm{mg} / \mathrm{Kg}$ and $500 \mathrm{mg} / \mathrm{Kg})$ as observed in this study suggest that the extract may have haematotoxic effect, and at very high concentration may induce anaemia in animals on prolong feeding. This finding, however, would require further investigation. Exposure to some chemicals, drugs or plant extracts, particularly at higher concentrations has been associated with red blood cell destruction, and haemolytic anaemia is a part of the clinical syndrome associated with intoxication. Synthetic or natural compounds capable of causing haemolysis do so by interacting with sulfhydryl groups, the inhibition of various enzymes and immune mechanisms, and the fragmentation of erythrocytes as they pass through the platelet-fibrin mesh or by unknown or poorly defined mechanisms. It is however assumed that the decrease or increase in the values of blood parameters investigated here may be attributed to a defence reaction against $A$. africana, which occurs by stimulation of erythropoiesis and leucopoiesis (Ihedioha et al., 2004). 


\section{Ajeigbe et al., Afr J Tradit Complement Altern Med. (2013) 10(5):236-243 http://dx.doi.org/10.4314/ajtcam.v10i5.4}

The virtue of Aspilia africana as pharmacological source has continued to gain world-wide recognition. This study further confirmed the earlier works on its efficacy in this regard. No doubt, good and effective haematopoietic function can be enhanced and maintained by the use of micronutrients found in this plant, as many enzymes in immune cells require the presence of these micronutrients and critical roles have been defined for iron, copper, selenium, flavonoids, vitamins $B_{1}, B_{2}$ and $\mathrm{C}$ in the maintenance of optimum haematopoietic and immune functions (Feder, 2008; Abii and Onuoha, 2011; Okwuosa et al., 2012; Enitan et al., 2012). From the data generated in this study, it can be concluded that aqueous extract of A. africana at different concentrations tested have varied stimulating effects on the haematological parameters investigated. If these findings are extrapolated to humans, they further underscore the haematopoietic stimulating properties of Aspilia africana.

\section{Acknowledgement}

The authors of this manuscript wish to acknowledge the support of the Senate Research Grant Committee of Igbinedion University, Okada under the chairmanship of Prof. Tonye Okorie for provision of funds for this study.

\section{References}

1. Abii, T. A. and Onuoha, E. N. (2011): The Chemical Constituents of the Leaf of Aspilia africana as a Scientific Backing to its Tradomedical Potentials. Agricultural Journal, 6: (1): 28-30.

2. ACF (2000): Gavage Procedure in Rat: Animal care and use Manual, Animal Care Facility, Laurentian University. Pp. 1-2.

3. Achonye, E. L. (1976): A pharmacological investigation of the haemostatic action of pressed leaf extract of Aspilia latifolia (Compositae), B. Pharm. thesis. Pharmacology \& Toxicology Department, University of Nigeria, 23-31.

4. Adeniyi, B. A. and Odufowora, R. O. (2000): In-vitro Anti-microbial Properties of Aspilia africana. African J. of Biomedical Research, 3(3):167-70.

5. Annon, (1980): Guide to care and use of experimental animal. Canadian Council of Animal Care. Ottowa Ontario, Canada, 1: 185-90.

6. Baker, F. J., Silverton, R. E. and Pallister, C. J. (2001a): Visual Red Cell Counts, the Full Blood Count. Introduction to Medical Laboratory Technology, Seventh edition, Pp. 356.

7. Baker, F. J., Silverton, R. E. and Pallister, C. J. (2001b): Battlement method, Differential Leucocyte Count. Int introduction to Medical Laboratory Technology, seventh edition, Pp. 352.

8. Balick, M. J. and Paul, A. C. (1996). Plants that heal. In their plants, people, and culture; the Science of ethnobotany. New York, Scientific American Library, Pp. 25-61.

9. Burkill, H. M. (1985): The Useful Plants of West Tropical Africa. 2nd Ed. Families A-D, Royal Botanic Gardem, Kew, 1: 446-7.

10. Burton, G. W., Joyce, D. and Ingold, K. U. (1983): Is Vitamin E the only Lipid Soluble Chain Leaving Antioxidant in Human Blood Plasma and Erythrocyte Membrane. Arch. Biochem. Biophys., 222: 228-90.

11. Cheesbrough, M. (2002a): PCV and Red Cell Indices, Haematological Tests in: Cheesbrough, M. (ed.). District Laboratory Practice in Tropical Countries, Part 2, Pp. 310 - 314.

12. Cheesbrough, M. (2002b): Sahli Acid Haematin Method, Measurement of Haemoglobin, Haematological Tests in: Cheesbrough, M. (ed.). District Laboratory Practice in Tropical Countries, Part 2, Pp. 307.

13. Cheesbrough, M. (2002c): Counting White Cells and Platelets, Haematological Tests in: Cheesbrough, M. (ed.). District Laboratory Practice in Tropical Countries, Part 2, Pp. 314 - 317.

14. Cheesbrough, M. (2002d): Differential White Cells Count, Haematological Tests in: Cheesbrough, M. (ed.). District Laboratory Practice in Tropical Countries, Part 2, Pp. $324-325$.

15. Enitan, S. S., Ajeigbe, K. O., Josiah, S. J. and Ehiaghe F. A. (2012): Haematological and Hepatotoxic potential of Onion (Allium cepa) and Garlic (Allium sativum) Extracts in Rats. European Journal of Medicinal Plant, 2(4):290-307

16. Esonu, B. O., Emennalom, O. O., Udedibia, A. B. I., Herbert, U., Ekpor, C. F., Okoli, E. C. and Iheukwumere, F. C. (2001): Performance and Chemistry of Weaners Pigs fed raw mucuna bean (Velvet bean) meal. Trop. Anim. Prod. Invest. 4:49-54.

17. Etim, N. N. and Oguike, M. A. (2011): Haematology and Serum Biochemistry of Rabbit Does Fed Aspilia africana. Nigerian Journal of Agriculture, Food and Environment. 7(4):121-127.

18. Eweka, A. O. (2008): Histological Studies of the Teratogenic Effects of Oral Administration of Aspilia africana (Asteracea) Extract on the Developing Kidney of Wistar Rats. The inter. Journal of Toxicology. 4(2).

19. Feder, B. J. (2008): Reguulators stamp copper as a germ killer. New York Times.

20. Frandson, R. D. (2003): Anatomy and Physiology of Farms Animals. Chap. 31. Pp. 462.

21. Garima S., Goyal P.K. (2007). Prevention of radiation induced haematological alterations by medicinal plant Rosmarinus officinalis in mice. Afri. J. Trad. CAM. 4(2):165-172. 

http://dx.doi.org/10.4314/ajtcam.v10i5.4

22. Hutchinson, J. (1962): Flora of West Tropical Africa Volume II. Mill Bank, London: Crown Agents for Overseas Government and Administration.

23. Ihedioha, J. T., Okafor, C. and Ihediola, T. E. (2004): The haematological profile of the Sprague Dawley out-bred albino rat in Nsukka. Anim. Res. Intern. 1:125-132.

24. Ihedioha, J. T., Okerie-Kanu, C. O. and Iwuogu, U. M. (2008): Leukocyte Alterations associated with continual sub-acute blood loss. Proc.of 33rd Annual Conf. of NASP, Ogun. Pp. 55-57.

25. Iheukwumere, F. C., Herbert, U., Iloeje, M. U. and Onyekwere, M. (2007): Physiological response of West African Dwarf does to progesterone injections: Haematology and serum biochemistry. Proc. of 32nd annual conf. of NSAP, 18-21, 79-82.

26. Ikpu, D.E., Nku, C.O. (2008): Effect of ethanolic extract of Dennettia tripetala parameters in albino wistar rats. Niger. Journal of Physiol. Sci. 23 (1-2), 13-17.

27. ILAR (1996): "Guide for the Care and Use of Laboratory Animals in Biomedical and Behavioral Research" In: Veterinary-Medical Care Manual. Institute for Laboratory Animal Research, American Academy of Sciences, Washington. Pp. 56-70.

28. Iwu, M. M. (1993): Handbook of African Medicinal Plants. CRP Press, Boca Raton Florida.

29. Kuaite, J.R., R.H.A. Zollo, G. Kammaty, C. Menut and J.M. Bessiere (1999): Composition of the essential oils from the leaves of two varieties of Aspilia africana (Pers.) C.D. Adams from Cameroon. Flavour Fragr. J., 14: 167-169.

30. Macfoy, C. A. and Cline, E. I. (1990): In-vitro antibacterial activities of three plants used in traditional medicine in Sierra-leone, J. Ethnopharmacol., 28(3): 232-7.

31. Masato, K. and Wu, Y. (1994): Chemistry of 1, 2-Dithins Synthesis of the Potent Antibiotic Thiarrubine A. Journal of American Chemical Society. 116: 10793-10794.

32. Mitruka, B. M. and Rawnsley, H. M. (1977): Clinical biochemical and haematology reference values in normal and experimental animals. Masson Publishing USA, Inc. Pp. 83,134-135.

33. Nguelefack, T.B., P. Watcho, S. Wansi, N. Mbonuh, D. Ngamga, P. Tane $\quad$ and A. Kamanyi, $2005 . \quad$ The antiulcer effects of the methanolic extract of the leaves of Aspilia africana (Asteraceae) in rats. $\quad$ Afr. $\quad J . \quad$ Trad. CAM., 2(3): 233-237.

34. Nwinuka, N.M., Monanu, M.O., Nwiloh, B.I. (2008). Effects of aqueous extract of Mangifera indica L. (mango) stem bark on haematological parameters of normal albino rats. Pak. J. Nutr. 7 (5): 663-666.

35. Nwosu, C. C. (1979): Characteristics of local chicken of Nigeria and its potential for egg and meat production. In: Poultry Production in Nigeria. Proc. Of 1st National Seminar on Poultry Production, Zaria.

36. Ochei, J., Kolhatkar, A. (2006): Euthanasia of Animals by Cervical Dislocation in: Ochei, J. and Kolhatkar, A. (eds.). Theory and Practice of Medical Laboratory Science. Tata McGraw- Hill publishing Company Limited, New Delhi. Pp. 1213-1230.

37. Odesanmi, S.O., Lawal, R.A., Ojokuku, S.A. (2010). Haematological effects of ethanolic fruit extract of Tetrapleura tetraptera in male Dutch White rabbits. Res. J. Med. Plant. 1-5.

38. Okoli, C. O., Akah, P. A. and Okoli, A. S. (2007): Potential of leaves of Aspilia africana (Composite) in wound care: an experimental evaluation. Biomedical Centre Complimentary and Alternative Medicine, 7(24): 101-109.

39. Okwuosa, C. N., Nwachukwu, D. C. and Azubuike, N. (2012): Effect of Aspilia africana on Necrotizing Agent Induced Gastric Ulcer and Gastric Motility. Indian Journal of Novel Drug delivery. 4(2): 110-114.

40. Oluyemi, K. A., Okwuonu, U. C., Baxter, D. G. and Oyesola, T. O. (2007): Toxic Effects of Methanolic Extract of Aspilia africana Leaf on the Estrous Cycle and Uterine Tissues of Wistar Rats. $\quad$ Int. J. Morphol., 25(3):609-614.

41. Onyeyili, P. A., Egwu, G. O., Jibike, G. I., Pepple, D. J. and Gbaegbulan, J. O. (1991): Seasonal variations in haematological indices in the grey-breasted guinea fowls (Numida meleagris gallata, Pallas). Nig. J. Anim. Prod. 18(2):108-111.

42. Oyedemi, S.O., Adewusi, E.A., Aiyegoro, O.A., Akinpelu, D.A. (2011). Anti-diabetic and haematological effect of aqueous extract of stem bark of Afzelia africana (Smith) on streptozotocin-induced diabetic Wistar rats. Asian Pacific J. of Trop. Biomed. 353-358. 